\title{
PAROLINE, RESTITUTION, AND TRANSFERRED SCIENTER: CHILd PORNOGRAPHY POSSESSORS AND RESTITUTION BASED on a Commerce Clause-Derived, Aggregate Proximate CAUSE THEORY
}

\author{
Adam Lamparello ${ }^{*} \mathcal{E}^{\circ}$ Charles E. MacLean ${ }^{* *}$
}

\section{INTRODUCTION}

Should possessors and manufacturers of child pornography be treated identically for purposes of victim compensation? Various circuit courts of appeals say no. ${ }^{1}$ The Fifth Circuit, in Paroline II, took a different approach and said yes. ${ }^{2}$ In an en banc opinion, the Fifth Circuit held that 18 U.S.C. $§ 2259$, the federal statute providing mandatory restitution for victims of child exploitation and abuse, does not require a causal link between the possession of child pornography and the resulting harm. The Fifth Circuit's holding now stands apart from all other circuits to have considered this question. These circuits have interpreted $\S 2259$ (b) (3) (F) ${ }^{3}$ — which explicitly requires causation - to modify the language of subparagraphs (A)-(E), thus importing a causation requirement into the entire statute. The United States Supreme Court has granted certiorari and will soon consider this question.

* Assistant Professor of Law, Indiana Tech Law School; B.A., magna cum laude, University of Southern California; J.D., with honors, Ohio State University College of Law; LL.M., New York University School of Law. Professor Lamparello would like to thank Pamela Hartig, a graduate of Mercer University's Walter F. George School of Law, for her invaluable insights and contributions throughout the development of this article.

** Assistant Professor of Law, Indiana Tech Law School; B.A., M.B.A., University of Minnesota; J.D., cum laude, William Mitchell College of Law.

1 See, e.g., United States v. Benoit, 713 F.3d 1, 22-23 (10th Cir. 2013); United States v. Laraneta, 700 F.3d 983, 991-92 (7th Cir. 2012); In re Amy, 698 F.3d 1151, 1152 (9th Cir. 2012); United States v. Burgess, 684 F.3d 445, 456-57 (4th Cir. 2012); United States v. Evers, 669 F.3d 645, 658-59 (6th Cir. 2012); United States v. Aumais, 656 F.3d 147, 15354 (2d Cir. 2011); United States v. Monzel, 641 F.3d 528, 535 (D.C. Cir. 2011), cert. denied, 132 S. Ct. 756 (2011); United States v. McDaniel, 631 F.3d 1204, 1208-09 (11th Cir. 2011).

2 In re Amy Unknown (Paroline II), 701 F.3d 749, 752 (5th Cir. 2012), cert. granted sub nom., Paroline v. United States, 133 S. Ct. 2886 (2013).

3 Subparagraph $(\mathrm{F})$, the "catchall" provision, provides that the term "full amount of the victim's losses" includes "any other losses suffered by the victim as a proximate result of the offense." 
The authors believe that both interpretations are wrong. The answer lies somewhere in the middle and can be found in the Court's Commerce Clause jurisprudence. Specifically, based upon the theory of "aggregation" as enunciated in a long line of cases defining the scope of Congress's Commerce Clause powers, the Court has held that individual (or intrastate) activity, while not sufficient in itself to affect interstate commerce, is nonetheless subject to regulation based on its cumulative effect. ${ }^{4}$ The same argument applies in the context of child pornography, where the victim's harm is connected to and intertwined with the individual possession (and viewing) of sexually explicit images. In the aggregate, possession of child pornography contributes to the victim's initial and continuing harm, and fuels an industry that exploits and abuses children. Thus, while the Fifth Circuit reached the right result, it used the wrong reasoning. The other circuit courts, however, unwisely require a relational nexus between the victim and the pornography possessor.

The aggregation theory, which establishes a limited nexus between possession and ultimate harm, strikes the right balance between a possessor's liberty interests and the victim's right to compensation for what is a unique-and continuing-harm. Each act of pornography possession contributes independently and continuously to the victim's harm by fueling the production of materials that exploit children. ${ }^{5}$ Put differently, since the harm suffered by victims of child pornography is sui generis, traditional rules of "but for" and proximate causation should not apply. An aggregate harm approach is fair and constitutes sound public policy-the touchstone considerations in proximate cause analysis. ${ }^{6}$

4 See Wickard v. Filburn, 317 U.S. 111, 127 (1942); see also Gonzales v. Raich, 545 U.S. 1, 19 (2005) (" $[\mathrm{P}]$ roduction of the commodity meant for home consumption, be it wheat or marijuana, has a substantial effect on supply and demand in the national market for that commodity."); United States v. Morales-de Jesús, 372 F.3d 6, 16 (1st Cir. 2004) ("In addition to our own precedent applying Wickard's principles to a child pornography statute in Robinson, the Supreme Court long ago recognized that child pornography is a commodity influenced by and subject to economic market forces." (citing Osborne v. Ohio, 495 U.S. 103, 109-10 (1990) (" $[\mathrm{I}] \mathrm{t}$ is "surely reasonable for the State to conclude that it will decrease the production of child pornography if it penalizes those who possess and view the product, thereby decreasing demand.'”))). In Morales-de-Jesús, the First Circuit held that Congress had the authority, under the Commerce Clause, to penalize the local production of pornography. While factually distinguishable from Paroline II, Morales-de-Jesús supports the notion that individual possession has a direct impact upon production and thereby contributes to the victim's harm. 372 F.3d at 16-17.

5 See, e.g., Osborne, 495 U.S. at 109-10; see also United States v. Kearney, 672 F.3d 81, 98 (1st Cir. 2012) ("Proximate cause therefore exists on the aggregate level, and there is no reason to find it lacking on the individual level.").

6 See, e.g., Palsgraf v. Long Island R.R. Co., 162 N.E. 99, 101-04 (N.Y. 1928) (Andrews, J., dissenting). 


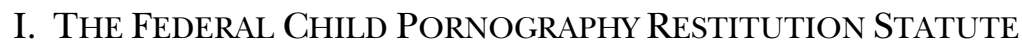 REQUIRES CAUSATION}

The federal child pornography restitution statute provides that restitution for the full amount of the victim's losses is mandatory in all child pornography convictions, including convictions for possessing child pornography. ${ }^{7}$ Of particular note, the statute incorporates causation into its terms: "the term 'victim' means the individual harmed as a result of a commission of a crime under this chapter." But the statute does not further define causation, presumably leaving to courts the definition of that word to apply. That being said, there is no doubt that under the child pornography federal statutory scheme, the paramount quests are interdiction and elimination of child pornography, and full compensation for the victims. Those twin quests can only be achieved through an aggregate proximate cause approach.

$7 \quad 18$ U.S.C. $\$ 2259$ (2006): Mandatory restitution.

(a) In general.-Notwithstanding section 3663 or 3663A, and in addition to any other civil or criminal penalty authorized by law, the court shall order restitution for any offense under this chapter.

(b) Scope and nature of order.-

(1) Directions.-The order of restitution under this section shall direct the defendant to pay the victim (through the appropriate court mechanism) the full amount of the victim's losses as determined by the court pursuant to paragraph (2).

(2) Enforcement.-An order of restitution under this section shall be issued and enforced in accordance with section 3664 in the same manner as an order under section 3663A.

(3) Definition.-For purposes of this subsection, the term "full amount of the victim's losses" includes any costs incurred by the victim for-

(A) medical services relating to physical, psychiatric, or psychological care;

(B) physical and occupational therapy or rehabilitation;

(C) necessary transportation, temporary housing, and child care expenses;

(D) lost income;

(E) attorneys' fees, as well as other costs incurred; and

(F) any other losses suffered by the victim as a proximate result of the offense.

(4) Order mandatory.-

(A) The issuance of a restitution order under this section is mandatory.

(B) A court may not decline to issue an order under this section because of-

(i) the economic circumstances of the defendant; or

(ii) the fact that a victim has, or is entitled to, receive compensation for his or her injuries from the proceeds of insurance or any other source.

(c) Definition.-For purposes of this section, the term "victim" means the individual harmed as a result of a commission of a crime under this chapter, including, in the case of a victim who is under 18 years of age, incompetent, incapacitated, or deceased, the legal guardian of the victim or representative of the victim's estate, another family member, or any other person appointed as suitable by the court, but in no event shall the defendant be named as such representative or guardian.

$8 \quad 18$ U.S.C. $\$ 2259$ (c) (emphasis added). 


\section{IN PAROLINE II, THE FIFTH CIRCUIT SHOUld HAVE INTERPRETED $\S 2259$ TO REQUiRe A CAUSAL NEXUS BETWEEN THE POSSESSION OF CHILD PORNOGRAPHY AND THE VICTIM'S HARM}

The Fifth Circuit, in Paroline II, reached the right result but erred in its reasoning. In that case, petitioner Doyle Paroline, who pled guilty to possessing 150 to 300 images of the victim, argued that an award of restitution was not proper unless it could be shown that his possessory acts proximately caused Amy's harm. ${ }^{9}$ The district court held that $\$ 2259$ required a showing of proximate cause, and denied restitution. $^{10}$ In its view, Amy had failed to demonstrate that Paroline's possession (and viewing) of her images proximately caused the ensuing harm. ${ }^{11}$

In Paroline II, which was consolidated with a similar appeal, the Fifth Circuit, sitting en banc, reversed. ${ }^{12}$ The court focused on the language of $\S 2259(\mathrm{~b})(3)(\mathrm{A})-(\mathrm{E})$, which listed five categories for which restitution could be awarded. ${ }^{13}$ Subparagraph (F), the "catchall" provision, authorized restitution for "any other losses suffered by the victim as a proximate result of the offense." ${ }^{\prime 4}$ Paroline argued that subparagraph (F)'s proximate cause language should be interpreted to modify and therefore import into subparagraphs (A)(E) a proximate cause requirement.

The Fifth Circuit disagreed. Applying the "rule of the last antecedent" canon of statutory construction, the court held that causation was only required for losses under subparagraph (F). ${ }^{15}$ The court explained that "the grammatical structure of $\S 2259$ (b) (3) reflects the intent to read each category of loss separate from the one that preceded it and limit the application of the 'proximate result' language in $\$ 2259(\mathrm{~b})(3)(\mathrm{F}) . "{ }^{\prime 6}$ Such an interpretation was based upon the statute's plain language and consistent with its "broad restitutionary

9 Paroline II, 701 F.3d at 752-53. The Fifth Circuit confronted the same issue in United States v. Wright, 639 F.3d 679, 683-85 (5th Cir. 2011), where it applied the holding in In re Amy Unknown (Paroline I), 636 F.3d 190 (5th Cir. 2011), and held that restitution under $\S 2259$ did not require causation. In Paroline II, both Wright's and Amy's appeal (from a district court order denying restitution) were heard together en banc.

10 United States v. Paroline, 672 F. Supp. 2d 781, 791 (E.D. Tex. 2009).

11 Id. at 793.

12 In In re Amy, the Fifth Circuit denied restitution because it was unclear whether $\$ 2259$ required a showing of proximate cause. 591 F.3d 792, 794 (5th Cir. 2009).

Paroline II, 701 F.3d at 760 .

Id. (emphasis added).

Id. at 765 .

Id. 
purpose,"17 which directs the "defendant to pay the victim ... the full amount of the victim's losses."

The Fifth Circuit reached the right result, but through reasoning that leads to unjust consequences. ${ }^{19}$ The Fifth Circuit's majority decision in Paroline II, in awarding restitution to the victim without any proximate cause requirement (1) is at odds with other circuits that have interpreted $\S 2259(\mathrm{~b})(3)(\mathrm{F})$; (2) threatens to disrupt the administration of unrelated federal statutes, which have applied the "series modifier" to similar "catchall" provisions; and (3) may impermissibly expand the transferred intent doctrine. In short, the court applied the wrong canon of statutory construction. It should have held that causation was required under each subparagraph-and used a non-traditional formulation to find that it was satisfied.

The First Circuit, in United States v. Kearney, ${ }^{20}$ however, got it right. The court recognized that, for purposes of restitution under $\S 2259$, causation should be predicated on aggregation. ${ }^{21}$ To hold otherwise would allow an entire class of individuals to escape liability for conduct that violates a child's personhood and perpetuates the widespread victimization of children. ${ }^{22}$ This result contravenes the express intent underlying 18 U.S.C. $\$ 2259$, which requires full restitution for "any offense" under Title 18, including possession. ${ }^{23}$ This was the correct-and fair-result. Below is a detailed discussion of how-and why—the Supreme Court should adopt the aggregation theory.

\section{POSSESSORS OF CHILD PORNOGRAPHY-INDIVIDUALLY AND COLLECTIVELY-CAUSE HARM TO THE VicTiM}

Proximate cause must be considered within the context of Congress's intent when enacting $§ 2259$, which expressly addressed the harms caused by both the producers and the possessors of child pornography. ${ }^{24}$

17 Id. at 760 .

18 Id. (quoting $\$ 2259(\mathrm{~b})(1))$.

19 Importantly, "[a]n apportionment system that spreads the effect of the penal goals of deterrence, retribution, and rehabilitation among the many convicted consumers of child pornography, while leading ultimately to the goal of full compensation for caused injury, fulfills the public purposes of restitution ...." United States v. Gamble, 709 F.3d 541, 553 (6th Cir. 2013) (emphasis added).

$20 \quad 672$ F.3d 81 (1st Cir. 2012).

$21 \quad I d$. at 98.

22 See United States v. Hardy, 707 F. Supp. 2d 597, 605 (W.D. Pa. 2010).

23 Section 2259(a) provides that a district court "shall order restitution for any offense under this chapter."

24 See United States v. Kearney, 672 F.3d 81, 97 (1st Cir. 2012) ("The restitution statute was enacted against a body of Supreme Court case law explaining the type of harm caused by 


\section{A. Possessors of Child Pornography Individually and Collectively Contribute to the Victim's Harm}

In United States v. Hardy, a federal district court noted,

Children are exploited, molested, and raped for the prurient pleasure of [defendant] and others who support suppliers of child pornography. These small victims may rank as 'no one else' in [defendant's] mind, but they do indeed exist .... Their injuries and the taking of their innocence are all too real. There is nothing 'casual' or theoretical about the scars they will bear from being abused for [defendant's] advantage.

....

... The simple fact that the images have been disseminated perpetuates the abuse initiated by the producer of the materials. Consumers such as [defendant] who 'merely' or 'passively' receive or possess child pornography directly contribute to this continuing victimization. Having paid others to 'act out' for him, the victims are no less damaged for his having remained safely at home $\ldots{ }^{25}$

Obviously, the federal district court in Hardy saw that causation could easily be tracked to the user or "mere possessor" of the material. And the First Circuit's approach properly balances the severity of an individual's conduct with the aggregate effects of possession. ${ }^{26}$ Proximate cause exists on an "aggregate level," even when "the harm suffered by the plaintiff might be the same if one of the numerous tortfeasors had not committed the tort." ${ }^{\prime 27}$

In Kearney, the defendant, who was convicted of transportation, possession, and distribution of child pornography, argued that "because so many have seen and distributed the pornography, his contribution cannot be said to have caused any harm absent specific linkage to [the victim's] knowledge about him." ${ }^{28}$ The First Circuit rejected this argument:

[I]t is true that [the expert report] does not state that any single additional instance of possession or distribution by itself increases the harm to [the victim]. But although such an explanation would be sufficient for a finding of causation, it is not necessary for such a finding. Kearney's conduct contributed to a state of affairs in which [the victim]'s emotional harm was worse than would have otherwise been the case. Proximate cause exists where the tortious conduct of multiple actors has combined to bring

distribution and possession of child pornography .... These cases make clear that injury to the child depicted in the child pornography ... . is a readily foreseeable result of distribution and possession of child pornography." (emphasis added)).

25707 F. Supp. 2d 597, 606 (W.D. Pa. 2010) (alteration in original) (quoting United States v. Goff, 501 F.3d 250, 259 (3d. Cir. 2007)).

26 Kearney, 672 F.3d at 98; see also Holmes v. Sec. Investor Prot. Corp., 503 U.S. 258, 268 (1992).

$27 \quad$ Kearney, 672 F.3d at 98.

28 Id. 
about harm, even if the harm suffered by the plaintiff might be the same if one of the numerous tortfeasors had not committed the tort. ${ }^{29}$

Indeed, "causation exists even where 'none of the alternative causes is sufficient by itself, but together they are sufficient' to cause the harm." ${ }^{30}$

As such, the Kearney court held that restitution under $\S 2259$ was not precluded simply because the victim "would have suffered harm in the absence of [defendant's] conduct." the notion that "the victim of child pornography could only show causation if she focused on a specific defendant's viewing and redistribution of her images and then attributed specific losses to that defendant's actions." "32 As the majority recognized, "[t]he 'logic' of this argument is that there would be no remedy for the harm suffered ... as a result of the redistribution and possession," thus allowing each defendant "to escape liability for a reason that, if recognized, would likewise protect each other defendant in the group." ${ }^{33}$

Finding causation in this context is not tantamount to strict liability; it reflects the notion that the intentional possession of child pornography is directly related to the resultant harm. ${ }^{34}$ The aggregate harm principle is also consonant with principles of fairness and

$29 \quad I d$. (emphasis added). The Kearney court claimed that its analysis was not a departure from traditional proximate cause principles in that it was foreseeable, by possessing child pornography, that the children depicted in the images would be harmed. The finding that causation existed on an "aggregate level" is less commonly invoked to justify a finding of "but for" proximate cause.

30 Id. (quoting Restatement (THIRd) OF TORTS: LiABILITy FOR PHySICAL AND EMOTIONAL HARM $\$ \$ 27$ reporters' n. cmt. g, $36 \mathrm{cmt}$. a (2010) ("[E]ven an insufficient condition ... can be a factual cause of harm when it combines with other acts to constitute a sufficient set to cause the harm. ...")); see also United States v. Veazie, No. 2:11-cr-202GZS, 2012 WL 1430540, at *3 n.4 (D. Me. Apr. 25, 2012) ("[P]roximate cause exists where the tortuous conduct of multiple actors has combined to bring about harm, even if the harm suffered by the plaintiff might be the same if one of the numerous tortfeasors had not committed the tort." (quoting Kearney, 672 F.3d at 98)).

$31 \quad I d$. at 99.

32 Id. (declaring that restitution is not precluded simply "because [defendant's] contribution to the harm cannot be precisely ascertained with exactitude").

33 Id.; see also United States v. Crandon, 173 F.3d 122, 126 (3d Cir. 1999) (finding that the defendant's conduct was a "substantial factor" in the victim's harm, despite the fact that the victim "suffered from pre-exiting, untreated psychological problems prior to" meeting the defendant).

34 See United States v. Solsbury, 727 F. Supp. 2d 789, 792 (D.N.D. 2010) ("The recipient of child pornography obviously perpetuates the existence of the images received, and therefore the recipient may be considered to be invading the privacy of the children depicted, directly victimizing these children." (quoting United States v. Norris, 159 F.3d 926, 930 (5th Cir. 1998))). 
sound public policy, which counsel against a mechanical application of the "but for" causation test.

Of course, there must be "some direct relation between the injury asserted and the injurious conduct," and not just "harm flowing merely from the misfortunes visited upon a third person by the defendant's acts." ${ }^{36}$ The causal connection, however, between even a single viewing of child pornography and the resultant harm is readily apparent. $^{37}$ In the aggregate, possession and distribution bear far more than "some direct relation"; they are the sine qua non for the initial and continuing harm that each victim suffers. To argue otherwise "defies both fact and law."

Aggregation is neither a novel nor an unworkable concept. In the Commerce Clause context, aggregation has-for nearly threequarters of a century-been the basis upon which the Supreme Court connected purely intrastate activities to its effects on interstate commerce. $^{39}$ In Wickard, the Court held that a local farmer's modest production of wheat, for purely intrastate purposes and selfconsumption, nonetheless had an aggregate effect of interstate commerce. $^{40}$

While an effect is not by implication a cause, it undoubtedly "contribute[s] to a state of affairs in which [the victim's] emotional harm was worse than would have otherwise been the case." ${ }^{\text {11 }}$ This is true, a

35 See, e.g., Palsgraf v. Long Island R.R. Co., 162 N.E. 99 (N.Y. 1928) (Andrews, J., dissenting); United States v. Tallent, 872 F. Supp. 2d 679, 686 (E.D. Tenn. 2012) (“[P]roximate cause essentially serves as a proxy for fairness. ... [C] ourts should limit liability on public policy grounds where holding the defendant liable would be unfair or unjust."); see also Holmes v. Sec. Investor Prot. Corp., 503 U.S. 258, 268 (1992) ("Here we use "proximate cause' to label generically the judicial tools used to limit a person's responsibility . . . A At bottom, the notion of proximate cause reflects 'ideas of what justice demands, or of what is administratively possible and convenient." (quoting W. KeEton, ET AL., Prosser AND KEETON ON LAW OF TORTS $§ 41$, at 264 (5th ed. 1984))).

36 Holmes, 503 U.S. at 268.

37 See Kearney, 672 F.3d at 95 ("Every instance of viewing images of child pornography represents a renewed violation of the privacy of the victims and a repetition of their abuse." (quoting Adam Walsh Child Protection and Safety Act of 2006, Pub. L. No. 109-248, $\S 501(2)(D), 120$ Stat. 587, 624)).

$38 \quad$ Kearney, 672 F.3d at 94.

39 Wickard v. Filburn, 317 U.S. 111, 127 (1942); see also United States v. Morales-de Jesús, 372 F.3d 6, 16 (1st Cir. 2004) (noting that the Supreme Court has reaffirmed the aggregation principle of Wickard while limiting its application to statutes regulating commercial or economic activities).

40317 U.S. at 127-28 ("That appellee's own contribution to the demand for wheat may be trivial by itself is not enough to remove him from the scope of federal regulation where, as here, his contribution, taken together with that of many others similarly situated, is far from trivial.").

41 United States v. Tallent, 872 F. Supp. 2d 679, 688 (E.D. Tenn. 2012) (quoting Kearney, 672 F.3d at 98). 
fortiori, because the possession of child pornography contributes to a continuing harm. ${ }^{42}$

\section{B. Traditional Proximate Cause Analysis Does Not Account for the Harm Caused By the Individual Possessors of Child Pornography}

Adhering to the traditional "but for" and foreseeability tests would involve the courts in an unworkable parsing of conduct that is often indivisible, and does not reflect the relationship between possession-by any individual —and the underlying harm. ${ }^{43}$

Requiring a direct connection between possession and the victim's actual losses, or notification to the victim of the specific defendant(s) who viewed such images, ${ }^{44}$ misperceives the harm that child pornography victims suffer. ${ }^{45}$ The harm does not lie in knowing who viewed the images, but in knowing that they were viewed at all. ${ }^{46}$ Knowing

42 Kearney, 672 F.3d at 94-95; see also Morales-de Jesús, 372 F.3d at 16. (“[P]ossessing child pornography fuels the demand side of the market ....").

43 Several circuit courts support a traditional application of proximate cause. The D.C. Circuit based its finding of a proximate cause requirement on "traditional principles of tort and criminal law, and on $\$ 2259$ (c)'s definition of 'victim' as an individual harmed 'as a result' of the defendant's offense." United States v. Evers, 669 F.3d 645, 658 (6th Cir. 2012) (quoting United States v. Monzel, 641 F.3d 528, 535 (D.C. Cir. 2011)). As the D.C. Circuit emphasized, "[i] t is a bedrock rule of both tort and criminal law that a defendant is only liable for harms he proximately caused." Evers, 669 F.3d at 658 (quoting Monzel, 641 F.3d at 535-36) (internal quotation marks omitted). Without such requirement, "liability would attach to all sorts of injuries a defendant might indirectly cause, no matter how 'remote' or tenuous the causal connection." Evers, 669 F.3d at 658 (quoting Monzel, 641 F.3d at 537) (internal quotation marks omitted). Put differently, "[a] general causation requirement without a subsidiary proximate causation requirement is hardly a requirement at all, because [s]o long as the victim's injury would not have occurred but for the defendant's offense, the defendant would be liable for the injury" Evers, 669 F.3d at 659 (alteration in original) (quoting Monzel, 641 F.3d at 537 n.8) (internal quotation marks omitted). As the Evers court held, " $[\mathrm{h}] \mathrm{ad}$ Congress meant to abrogate the traditional requirement for everything but the catch-all, surely it would have found a clearer way of doing so." Evers, 669 F.3d at 658-59 (quoting Monzel, 641 F.3d at 536-37). See also Brief for Professors Adam Lamparello and Charles MacLean as Amici Curiae Supporting Neither Party, Paroline v. United States, (filed Nov. 19, 2013) (No. 12-8561), 2013 WL 6235571 ("such an approach would 'erect an 'impossible burden' on the victims' statutory right to restitution and frustrate the express purpose of $§ 2259$ ["]) (citing Brief for Respondent at 26).

44 See, e.g., United States v. Kennedy, 643 F.3d 1251, 1263 (9th Cir. 2011) (suggesting that causation is satisfied where the victim knows the identity of those who have viewed her images).

45 See United States v. McGarity, 669 F.3d 1218, 1269 (11th Cir. 2012) (“[F]or proximate cause to exist, there must be a causal connection between the actions of the end-user and the harm suffered by the victim.").

46 United States v. Hardy, 707 F. Supp. 2d 597, 605 (W.D. Pa. 2010) (“[The original victim]'s appearance in images held by Defendant make her an 'individual harmed as a result of a commission of a crime' under $\$ 2259$, and therefore a victim for purposes of ordering restitution under $§ 2259$.” (emphasis added)). 
that these images exist and are available for public consumption causes the emotional and psychological damage that $\S 2259$ is intended to address.

This fact dispels any notion that possession of child pornography is a victimless crime. As the court in Kearney held,

The Supreme Court has repeatedly explained, for thirty years, that individuals depicted in child pornography are harmed by the continuing dissemination and possession of such pornography containing their image. Such materials are "a permanent record of the children's participation and the harm to the child is exacerbated by their circulation." ... Indeed, the Court has stated that "as a permanent record of a child's abuse, the continued circulation itself would harm the child who had participated. Like a defamatory statement, each new publication of the speech would cause new injury to the child's reputation and emotional wellbeing." ${ }^{47}$

That is precisely why "aggregate level" causation is justified. ${ }^{48}$

This is not to suggest that anyone convicted of possession will face "infinite liability, or be responsible for harms that occur prior to the crime's commission." ${ }^{49}$ Conduct that might not otherwise be causally related to the victim's harm, however, can become so when, together with the conduct of others, it contributes to "repetition of [the victim's] abuse." ${ }^{, 50}$ Possession causes harm because the lifeblood of production is individual consumption.

\section{The Fifth Circuit's Decision in Paroline I Disregarded the "Series Modifier" and Leads to Unjust Results}

\section{The Fifth Circuit's Decision Has the Potential to Disrupt the Orderly Administration and Interpretation of Unrelated Federal Restitution Provisions}

The Fifth Circuit erred when holding that $§ 2259$ (b) (3) (A)-(E) did not require proximate cause. The majority's opinion relied on the rule of the last antecedent to hold that $\$ 2259$ (b) (3) "limit[ed] the phrase 'suffered by the victim as a proximate result of the offense'

47 Kearney, 672 F.3d at 94 (quoting New York v. Ferber, 458 U.S. 747, 759 (1982); Ashcroft v. Free Speech Coal., 535 U.S. 234, 249 (2002)).

48 Kearney, 672 F.3d at 98.

49 Brief for Professors Adam Lamparello and Charles MacLean as Amici Curiae Supporting Neither Party, supra note 43, at 14-15; see also United States v. Ageloff, 809 F. Supp. 2d 89, 104 (E.D.N.Y. 2011) ("[Restitution requires] reasonable estimates arrived at by a preponderance of the evidence.").

50 Kearney, 672 F.3d at 95 (quoting Adam Walsh Child Protection and Safety Act of 2006, Pub. L. No. 109-248, § 501(2)(D), 120 Stat. 587, 624). 
in $\S 2259(\mathrm{~b})(3)(\mathrm{F})$ to the miscellaneous 'other losses' contained in that subsection."

In so doing, the Fifth Circuit disregarded the "series modifier" canon, which would have incorporated the proximate cause requirement for all subparagraphs $\S 2259$ (b) (3) (A-E)). ${ }^{52}$ The Fifth Circuit's interpretation is inconsistent with other circuits that have interpreted $\S 2259$ (b) (3) (F), as well as unrelated federal statutes. ${ }^{53}$ Accepting the Fifth Circuit's rationale, therefore, has the potential to create disharmony in the administration of various federal criminal restitution statutes.

\section{The Fifth Circuit's Decision Threatens to Impermissibly Transfer Scienter}

When enacting $\S 2259$, "Congress made no distinction between the various actors involved in the production, distribution, receipt and possession of child pornography, notwithstanding the strong possibility the culpability of these actors varies. ${ }^{, 54}$ Importantly, given that the lesser-included offense of possessing child pornography is inextricably linked with the harm resulting from its manufacture and distribution, it is just to subject both possessors and manufacturers to restitution.

51 Paroline II, 701 F.3d at 762; see also United States v. Benoit, 713 F.3d 1, 20 (10th Cir. 2013) (providing that the rule of last antecedent states that a limiting phrase "should ordinarily be read as modifying only the noun or phrase it immediately follows" (quoting Barnhart v. Thomas, 540 U.S. 20, 26 (2003))).

52 Analogous federal statutes support the conclusion that application of the "series modifier" would have been consistent with Congress's intent when enacting \$ 2259. See, e.g., Victim and Witness Protection Act of 1982, Pub. L. No. 97-291, 96 Stat. 1248; Violent Crime Control and Law Enforcement Act of 1994, Pub. L. No. 103-322, 108 Stat. 1796, 1907-10; and Antiterrorism and Effective Death Penalty Act of 1996, Pub. L. No. 104-132, 110 Stat. 1214 (incorporating the criminal restitution statutes 18 U.S.C. $\$ \S 3663$ (a) (2), $3663 \mathrm{~A}(\mathrm{a})$ (2), and 3771 (e), which define the term "victim" as "a person directly and proximately harmed" by conduct that justified an award of restitution).

53 See, e.g., United States v. Fast, 709 F.3d 712, 721 (8th Cir. 2013). In Fast, the Eighth Circuit considered whether the fact that $\$ 2259(\mathrm{~b})(3)(\mathrm{A})-(\mathrm{E})$, which, unlike $\$ 2264$ (b) (3) (A)-(E), enumerated specific categories of losses, meant that subparagraphs (A) -(E) of $\$ 2259$ (b) (3) did not require proximate cause. The Eighth Circuit answered this question in the negative, holding that "the variation among these restitution statutes d[oes] not mean that Congress eliminated the proximate cause requirement for the specifically enumerated losses in subsections 2259(b) (3) (A) through (E)." Id. See also United States v. Hayes, 135 F.3d 133, 137 (2d Cir. 1998) (applying the series modifier to hold that the proximate cause language in $\S 2264(\mathrm{~b})(3)(\mathrm{F})$, which authorized restitution for interstate domestic violence, 18 U.S.C. $§ 2261$; interstate stalking, 18 U.S.C. $\$ 2261 \mathrm{~A}$; and interstate violation of protection orders, 18 U.S.C. $\$ 2262$, applied to subparagraphs (A)(E)).

54 United States v. Tallent, 872 F. Supp. 2d 679, 682 (E.D. Tenn. 2012). 
In other contexts, however, such a result would be unjust and contrary to law. ${ }^{55}$ For example, there are significant differences between interstate domestic violence and interstate violation of a protective order. ${ }^{56}$ If the Fifth Circuit's decision were followed in contexts other than child pornography, crimes of varying culpability would, in effect, be construed as causing the same harm and subject different defendants to the same restitution statute. ${ }^{57}$

Such an interpretation would, de facto, transfer the scienter of a defendant who committed a more serious crime to the defendant who committed a lesser-and often dissimilar-crime. Such an approach violates the well-established limits on transferred intent. ${ }^{58}$

The Fifth Circuit's interpretation, therefore, threatens to undermine the administration of criminal restitution statutes and to collapse crimes of different severity into a single remedial category. If Congress wished to effectuate such a result, it would likely have been more explicit. Congress certainly would not have included the words "proximately caused" in subparagraph $(\mathrm{F})$, when the courts have used the series modifier canon to apply it equally to all preceding sections. $^{59}$

Ultimately, the approach adopted in Kearney reflects the unique harm that child pornography victims face and recognizes that possession of child pornography contributes to an aggregate harm, thus making possession a direct and proximate cause of that harm.

55 With respect to culpability, the differences between possession and production are evidenced by the penalties imposed under federal law. Under 18 U.S.C. $§ 2251$ (a), defendants convicted of producing child pornography face a minimum sentence of fifteen years and a maximum of thirty, per 18 U.S.C. $\$ 2252(\mathrm{e})$. Pursuant to 18 U.S.C. $\S 2252$ (a) (4) (B), however, defendants only convicted of possession face a maximum term of ten years.

$56 \quad$ See 18 U.S.C. $\$ \S 2261-62$.

57 Of course, courts have the discretion to apportion a restitution award based on the particular circumstances of a case. The fact remains, however, that individuals convicted of different crimes would potentially face the same restitution award. This goes against the basic notion in criminal law that criminal sanctions vary depending on the severity of the crimes.

58 United States v. Pulungan, 569 F.3d 326, 330-31 (7th Cir. 2009) (“[T]ransferring intent from one genus of offense to another has never been permitted.”).

59 See, e.g., United States v. Gamble, 709 F.3d 541, 548 (6th Cir. 2013) (noting, in the context of $\S 2259$, that "Congress [is] presumed to have legislated against the backdrop of our traditional legal concepts which render [proximate cause] a critical factor, and absence of contrary direction here [is] taken as satisfaction [of] widely accepted definitions, not as a departure from them" (alterations in original) (quoting United States v. U.S. Gypsum Co., 438 U.S. 422, 437 (1978) (internal quotation marks omitted))). 


\section{CONCLUSION}

Paroline represents a clash between victims' rights and the protections that should be afforded to criminal defendants. Victims of child pornography suffer the type of harm that cannot be overstated, and it results from despicable acts of abuse and exploitation. Importantly, however, possessors of child pornography are arguably less culpable than manufacturers and should be penalized differently. Ordinarily, this argument would have substantial merit-subjecting different categories of offenses to the same potential penalty could affront due process of law and raise Eighth Amendment proportionality concerns.

The child pornography context, however, is unique. The interdependent relationship between possessors and manufacturers of child pornography contributes to a life-altering, aggregate harm to young children, thereby justifying a restitutionary award that would otherwise be hard to apportion. The correct approach, however, is not to dispense with causation altogether, or to adopt the traditional rules of proximate causation. An aggregation approach properly balances the defendant's due process guarantees with the victim's interest in full restitution, thus achieving the goals that $\S 2259$ sought to achieve. 